\title{
Headspace Volumetric Karl Fischer Titration for the Determination of Water Content in Finished Tobacco Products *
}

\author{
by Nehabat Aydin, Florian Chardonnens, and Michel Rotach
}

Philip Morris International R\&D, Philip Morris Products S.A., 5 Quai Jeanrenaud, 2000 Neuchâtel, Switzerland

\section{SUMMARY}

Because many physicochemical properties of tobacco are highly sensitive to its moisture content, the determination of water level is an important parameter for tobacco characterization. A headspace volumetric Karl Fischer titration (HS-V-KFT) method is presented for the quantification of water content in different finished tobacco materials. The parameters affecting the extraction of water from the tobacco materials were the sample size and the oven temperature which have been optimized. The extraction of water from the samples was achieved within a reasonable time $(<25 \mathrm{~min})$ with a sample size of $200 \mathrm{mg}$ and an optimum temperature of between $90{ }^{\circ} \mathrm{C}$ and $100{ }^{\circ} \mathrm{C}$. The results of the water determination by HS-V-KFT at the optimized parameters were in good agreement with those obtained by standard volumetric Karl Fischer titration. HS-V-KFT showed very good repeatability $\left(\mathrm{RSD}_{\mathrm{r}} 0.9 \%\right)$ and intermediate precision $\left(\mathrm{RSD}_{\mathrm{iR}} 1.1 \%\right)$. With respect to a considerable time saving, solvent consumption reduction, precision and accuracy, HS-V-KFT can therefore be suggested as the method of choice to determine water amount in finished tobacco products. [Beitr. Tabakforsch. Int. 25 (2012) $350-359]$

\section{ZUSAMMENFASSUNG}

Da viele physikochemische Eigenschaften von Tabak sehr sensitiv zum jeweiligen Wassergehalt sind, ist die Wassergehaltsbestimmung ein wichtiger Parameter zur Charakterisierung von Tabak. Eine Kombination aus Headspaceanalyse und maßanalytischer Karl-Fischer-Titration
(HS-V-KFT) zur Bestimmung des Wassergehalts in verschiedenen prozessierten Tabakmaterialien wird im Folgenden vorgestellt. Die Parameter, wie die Probengröße und die Ofentemperatur, die die Extraktion von Wasser aus verschiedenen prozessierten Tabakmaterialien beeinflussen, wurden optimiert. Die Extraktion wurde in einer angemessenen Zeit $(<25 \mathrm{~min})$ bei einer Probengröße von $200 \mathrm{mg}$ und einer optimalen Temperatur zwischen $90{ }^{\circ} \mathrm{C}$ and $100{ }^{\circ} \mathrm{C}$ erreicht. Die Ergebnisse der Wassergehaltsbestimmung mittels HS-V-KFT bei optimierten Parametern zeigten eine gute Übereinstimmung mit Ergebnissen erzielt mittels Standard maßanalytischer Karl-Fischer-Titration. Die HS-V-KFT lieferte eine sehr gute Wiederholbarkeit $\left(\mathrm{RSD}_{\mathrm{r}} 0.9 \%\right)$ und interne Vergleichspräzision $\left(\mathrm{RSD}_{\mathrm{iR}} 1.1 \%\right)$. Unter Beachtung der erreichten Zeitersparnis, Lösungsmittelreduktion, Genauigkeit und der Richtigkeit der HS-V-KFT wird diese daher als eine geeignete Methode zur Wassergehaltsbestimmung in prozessierten Tabakprodukten empfohlen. [Beitr. Tabakforsch. Int. 25 (2012) 350-359]

\section{RESUME}

La détermination de la concentration d'eau dans le tabac est un important paramètre pour la caractérisation du tabac car de nombreuses propriétés physico-chimiques sont sensibles à sa teneur en eau. Une méthode de titration volumétrique Karl Fischer par espace de tête (HS-V-KFT) est présentée pour la quantification de la teneur en eau présente dans différents produits finis du tabac. Les paramètres tels que la taille de l'échantillon et la température du four ont été optimisés en raison de leur importance pour l'extraction de l'eau dans les tabacs. L'extraction de l'eau 
des échantillons a été effectuée dans un temps raisonnable ( $<25 \mathrm{~min}$ ) pour un échantillon de $200 \mathrm{mg}$, avec une température optimale de $90^{\circ} \mathrm{C}$ à $100{ }^{\circ} \mathrm{C}$. Les résultats de la détermination de l'eau par HS-V-KFT en utilisant les paramètres optimisés ont été en ligne avec ceux obtenus avec la méthode standard de titration volumétrique par Karl Fischer. La méthode HS-V-KFT a permis d'obtenir une très bonne répétabilité (RSDr $0.9 \%$ ) et précision intermédiaire (RSDiR 1.1\%). Compte tenu du gain de temps considérable lié à cette méthode, de la diminution de de solvants requis, de sa précision et son exactitude, la méthode HS-V-KFT peut donc être une méthode de choix pour la détermination de l'eau dans les produits finis du tabac. [Beitr. Tabakforsch. Int. 25 (2012) 350-359]

\section{INTRODUCTION}

For decades, measuring the moisture content in tobacco products during industrial processing has been of particular interest. Tobacco (Nicotiana tabaccum L.) is a complex material composed of a large variety of chemical compounds, from low to high molecular weight, including inorganic salts, carbohydrates, amino acids, alkaloids, isoprenoids, and carboxylic acids (1). Like many plants, tobacco cured leaf is a hygroscopic material with the propensity for exchange of moisture between its lamina and the surrounding atmosphere. Indeed from the time it is harvested until it becomes a finished product, tobacco undergoes a series of physical and biochemical changes accompanied by considerable exchange of moisture (sorption from and desorption to the surrounding atmosphere). One of the most important moisture transfer process in tobacco occurs during curing where the green high moisture content leaf at harvest is converted to the brown low moisture leaf stored in warehouses $(2,3)$. BABBITT (4) was among the first to study the exchange of moisture with the surrounding atmosphere for wheat, flour, and other food products. Tobacco-water interactions have been largely described in the literature $(2,5,6)$.

The determination of the moisture level at different stages of tobacco's lifecycle is an essential operation for quality control reasons. Indeed the adjustment of the humidity of tobacco and its control is an important parameter during curing, fermentation, packing, for the storage of raw tobacco in warehouses and marketing and sale of finished tobacco products.

It is well known that many physicochemical properties of tobacco, e.g., friability, heat capacity, thermal diffusivity, and combustion, are highly sensitive to its moisture content (7). Finished tobacco that has too high water content and is not suitably preserved will develop mould, leading to spoilage during storage. Conversely, very dry tobacco will be reduced to scraps, fines, and dust during handling and manufacturing. Thus, the ideal moisture level in finished tobacco fillers ready to be used in the manufacturing of cigarettes has to be adjusted to a value between 9 to $15 \%$ to preserve the quality, appareance and shelf-life of the final product.

The control of the tobacco humidity is not only an important parameter for quality control but also in commercial transactions and sales of finished products as tobacco dry weight is the basis for taxes in some countries. Moreover, the determination of the tobacco humidity is required whenever the level of specific tobacco components, e.g., nicotine, sugars, tobacco alkaloids, tobacco specific nitrosamines is reported on a dry weight basis for comparison reasons.

Various techniques have been documented on the measurement of the moisture content in tobacco materials. Examples of these are azeotropic distillation with benzene and cyclohexane (8-14), microwave heating (15), drying oven $(10,12,16)$, standard Karl Fischer titration $(17,18)$ and gas chromatography (19). However these techniques have several disadvantages when used for the quantification of water in tobacco samples. Azeotropic distillation with benzene was one of the standard methods used for water determination in tobacco in the sixties. Although due to its carcinogenicity, benzene was replaced later by cyclohexane $(8,10)$; the analysis of water by this method takes $2-3$ $\mathrm{h}$ per sample and needs at least 50 grams of tobacco. The oven method for determination of tobacco moisture is connected with the risk of wrong results due to tobacco volatiles. The standard volumetric Karl Fischer titration (V-KFT) and the gas chromatography method with thermal conductivity detector require long sample preparation steps, consume large quantities of solvent and are rather tedious and labor intensive for routine measurements (17-19). Other on-line techniques are available (e.g., microwave, infrared, etc.), but most of them must be calibrated by suitable off-line methods, e.g., by Karl Fischer. In order to improve these drawbacks and to increase sample throughput, a rapid Karl Fischer titration method based on headspace technique (HS-V-KFT) using potentiometric end point detection has been established and optimized. The major benefits of the headspace technique are that sample preparation and pre-treatment are no longer required, that matrix effect, and possible interfering reactions of, for instance, aldehydes and ketones with the Karl Fischer reagent (12) are eliminated. In addition to that the system allows an automation of the analytical sequence resulting in a considerable time saving.

This paper presents a fast, accurate, and reproducible method based on a headspace technique for the quantification of water concentration in different finished tobacco samples.

\section{MATERIALS AND METHODS}

\section{Standards and reagents}

Sodium tartrate dihydrate (water content: $15.66 \pm 0.05 \%$ ), hydranal-water standard KF oven (water content: $5.11 \pm 0.02 \%$ ) and apura-water oven standard (water content: $1.00 \pm 0.03 \%$ ) were purchased from Riedel-de-Haën (Seelze, Germany) and Merck (Darmstadt, Germany). The recommended oven temperatures were $160^{\circ} \mathrm{C}$ for sodium tartrate dihydrate, between $140{ }^{\circ} \mathrm{C}$ and $160{ }^{\circ} \mathrm{C}$ for hydranal-water standard $\mathrm{KF}$ oven, and $170{ }^{\circ} \mathrm{C}$ for apurawater oven standard.

The titration was performed with a one-component reagent, hydranal composite 5 (containing diethyleneglycol monoethyl ether, 2-methylimidazole, sulfur dioxide, and 
iodine) with a water equivalent of approximately $5 \mathrm{mg}$ $\mathrm{H}_{2} \mathrm{O} / \mathrm{mL}$, supplied by Riedel-de-Haën (Germany). Methanol, Romil-sps super quality solvent (water content below $0.02 \%$ ), was used as working medium and extraction solvent.

\section{Samples}

Five different tobacco sample candidates stored under ambient humidity conditions were used in this study. Type A was a cut filler used in a commercial cigarette, $C$ and D were cast leaf shreds with and without flavors, and types B and $\mathrm{E}$ were extruded tobaccos with and without flavors.

\section{Apparatus and procedure}

Direct volumetric Karl Fischer titration (V-KFT) measurements were carried out at room temperature using a Titrino titrator 841 (Metrohm, Herisau, Switzerland) equipped with a $250 \mathrm{~mL}$ titration vessel, an 801 magnetic stirrer, an 800 exchange unit $(10 \mathrm{~mL}$ and $50 \mathrm{~mL})$, and a double platinum electrode. Titration parameters were a start and stop drift of $10 \mu \mathrm{L} / \mathrm{min}$, a polarization current of $50 \mu \mathrm{A}$, and end point detection voltage of $250 \mathrm{mV}$. The titration was stopped when the final voltage of $250 \mathrm{mV}$ and the end point drift of $10 \mu \mathrm{L} / \mathrm{min}$ were reached. Prior to any analysis, the titer of the reagent was determined by injecting $20 \mu \mathrm{L}$ of deionized water (MilliQ) in triplicates into the titration cell.

The extraction of water from the tobacco samples for direct volumetric Karl Fischer titration measurements was performed in duplicate by adding $50 \mathrm{~mL}$ of methanol to $1 \pm 0.01 \mathrm{~g}$ of sample. The mixture was then shaken for $2 \mathrm{~h}$ at $220 \mathrm{rpm}$ using a Unimax 2010 orbital platform shaker (Heidolph Instruments, Switzerland). The mixture was then allowed to stand for $15 \mathrm{~min}$ to separate the liquid and solid phases. After decantation, $5 \mathrm{~mL}$ of the supernatant methanolic extract was injected into the titration cell. Traces of water in the atmosphere or vessels were subtracted from the water content in the samples. Water traces in blank samples were determined in triplicate using the same procedure as for real samples.

Headspace volumetric Karl Fischer titration (HS-V-KFT) was conducted with the above-described volumetric system connected with an automated 774 oven sample processor manufactured by Metrohm (Herisau, Switzerland). The titration parameters were the same as for standard volumetric Karl Fischer titration (start and stop drift of $10 \mu \mathrm{L} / \mathrm{min}$, a polarization current of $50 \mu \mathrm{A}$, and end point detection voltage of $250 \mathrm{mV}$ ) including a minimum extraction time of $150 \mathrm{~s}$ to avoid the titrator stopping before the complete release of water.

The determination of water by HS-V-KFT was performed by introducing standards and sample masses (200 to $400 \pm 10 \mathrm{mg}$ ) into $6 \mathrm{~mL}$ sample vials (Metrohm, Herisau, Switzerland). The sample vials were hermetically sealed using crimp caps containing a septum. A system-conditioning vial (empty), together with the sample vials were placed on the 774 oven sample processor. The release of water was performed by heating in an oven the sample vials at the optimum extraction temperature. The transfer of water in the headspace, released from the heated sam- ples, to the titration cell was carried out by a stream of dried air at a flow rate of between 55 and $60 \mathrm{~mL} / \mathrm{min}$. The transfer line of the 774 oven sample processor was maintained at $50{ }^{\circ} \mathrm{C}$ in order to prevent the condensation of water vapor during the transfer. The results were calculated using the software Tiamo version 1.2 (Metrohm).

\section{Working principle of the HS-V-KFT system}

KESTENS and co-workers previously employed a 774 oven sample processor in combination with coulometric Karl Fischer titration for the quantification of water in difficult matrix reference materials (20). The working principle of the automated system is based on heating in an oven, a closed glass vial containing a pre-weighed sample amount. A double hollow needle penetrates the sample vial that is heated to an appropriate temperature. The needle penetrates the sample vial by only a few centimeters in order to prevent contamination of the needle tip by substances that might adhere to it. A continuous and complete extraction of water from the heated solid matrix into the gas phase (headspace) and a dynamic purging of the headspace above the sample to the titration cell are ensured with a dry carrier gas.

Headspace volumetric Karl Fischer titration (HS-V-KFT) is a technique identical to dynamic gas purging headspace (DHS) $(21,22)$, with the exception that the analyte of interest in the purged headspace above the sample is not trapped on an adsorbent and thermally desorbed, but is transported directly into the titration vessel via the transfer line of the 774 oven sample processor. In the titration cell, a stoichiometric reaction between sulfur dioxide and iodine takes place in the presence of water and 2-methylimidazole. The role of the base is to buffer the titration system and stabilize the $\mathrm{pH}$ around the ideal value of 5, thus ensuring a rapid and stochiometric course of the reaction $(23,24)$.

\section{RESULTS AND DISCUSSION}

\section{Performance of HS-V-KFT system}

The performance of the combined system, HS-V-KFT, was assessed by measuring the water level in three reference materials and comparing the results with the certified values. In addition, the influence of water traces in the surrounding atmosphere was investigated by measuring three blanks. Three hermetically sealed empty vials were placed on the oven sample processor at the beginning of the analytical sequence followed by the sample vials containing $200 \pm 10 \mathrm{mg}$ of reference materials.

Figure 1 shows a graphical representation of a nine-fold water determination for sodium tartrate dihydrate and hydranal-water standard before and after subtracting three blanks. The determination of blank values was performed under the same conditions as the analysis of the standards. The mean (in $\mathrm{mL}$ ) of the blank value determinations was taken into account when calculating the results (subtracted). The results showed that subtracting the three blanks had no effect on the variability of the combined system, i.e., the relative standard deviations remained un- 
changed (Table 1). Nevertheless, a slight effect on the experimental mean concentration of water in each reference material was observed as shown in Table 1. Accordingly, three blanks were included in the analytical sequence when analyzing the tobacco samples.

The results of the water determination from the average of nine replicate measurements after the subtraction of water traces in blanks for the three reference materials are summarized in Table 1. Recoveries were on average 95\%, $99.7 \%$, and $101.6 \%$ for apura-water oven standard, hydranal-water standard, and sodium tartrate dihydrate, respectively. Moreover the combined system showed a very low variability when performing multiple measurements on a given material, as illustrated by the RSD values of below $1.6 \%$.

\section{Effect of sample size and extraction temperature optimization}

All tobacco samples investigated in this study were processed differently and present differences in their structure; therefore, it was supposed that they would behave in a different way when exposed to heat. Consequently, a suitable extraction temperature needed to be determined for each material. The oven temperature should be high enough to allow the transfer of water from the samples into the gas phase within 10 to 25 minutes, whereas overheating may result in additional water formation caused by decomposition or condensation reactions in food products as previously reported by KESTENS et al. (20).

For samples with unknown thermal behavior, the optimum oven temperature for extracting the water content can be determined by recording a so-called temperature ramp. The amount of water released and the drift are recorded simultaneously as a function of temperature and extraction time. The extraction time is obtained from the titration curve when the end-point detection is reached. It is defined as the time needed to release all the water from a sample at a determined temperature. An adequate extraction temperature profile was thus established for two tobacco samples (A and B) using the gradient temperature program. Approximately $200 \mathrm{mg}$ of sample was weighed into $6 \mathrm{~mL}$ sample vial and heated from $70{ }^{\circ} \mathrm{C}$ to $160^{\circ} \mathrm{C}$ at a heating rate of $2^{\circ} \mathrm{C} / \mathrm{min}$.

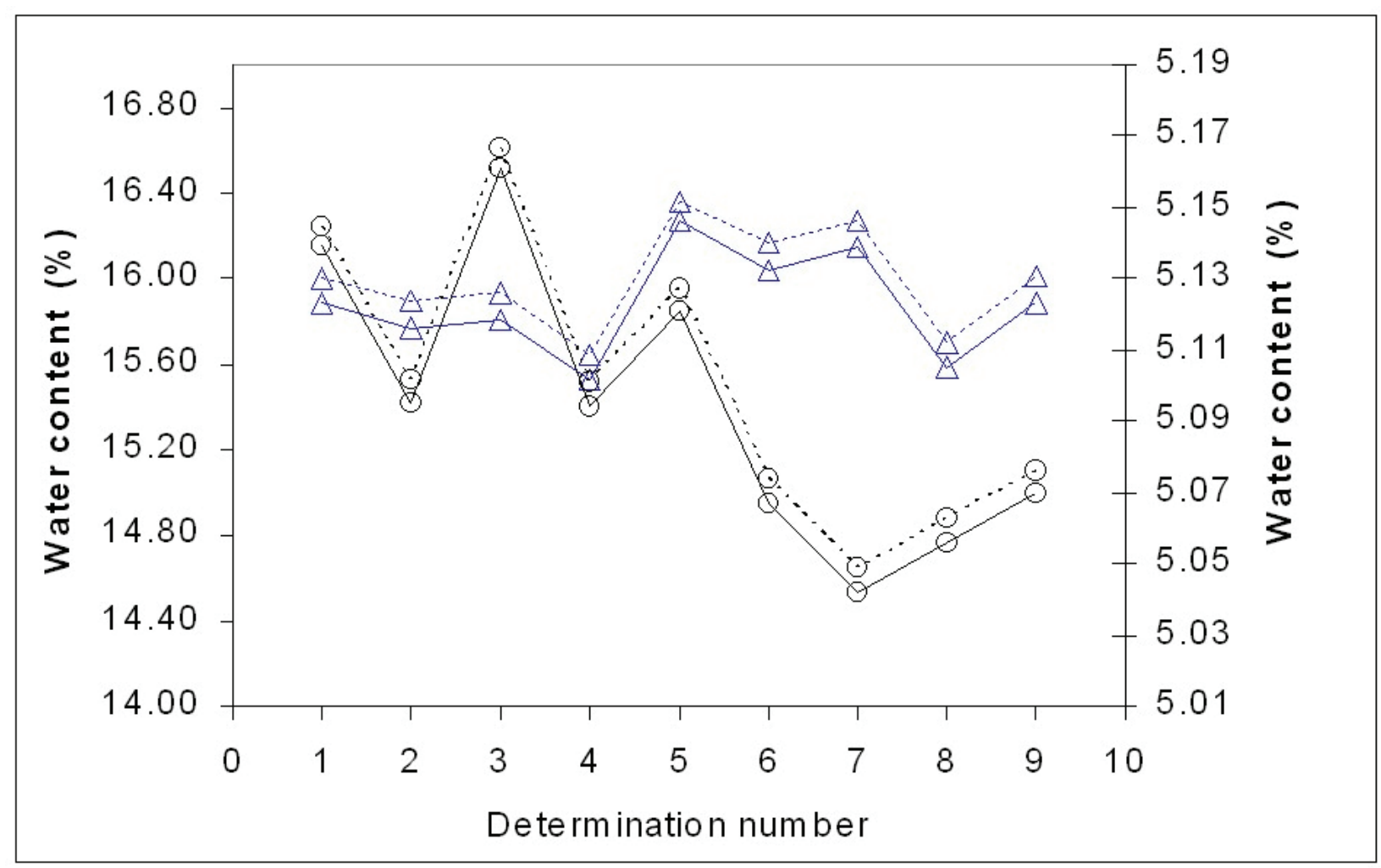

Figure 1. Water content determined in reference materials.

$\begin{array}{ll}\circ & \text { hydranal-water standard } \\ \Delta & \text { sodium tartrate dihydrate } \\ \text { dashed line } & \text { before blank subtraction } \\ \text { solid line } & \text { after blank subtraction } \\ \text { right axis } & \text { water content in hydranal water standard } \\ \text { left axis } & \text { water content in sodium tartrate dehydrate }\end{array}$


Table 1. Results of water determination $(n=9)$ in reference materials by HS-V-KFT before and after subtracting three blanks.

\begin{tabular}{|c|c|c|c|c|c|c|c|}
\hline & $\begin{array}{c}\text { Reference } \\
\text { material }\end{array}$ & $\begin{array}{c}\text { Certified water } \\
\text { content (\%) }\end{array}$ & $\begin{array}{c}\text { Temperature } \\
\left({ }^{\circ} \mathrm{C}\right)\end{array}$ & $\begin{array}{c}\text { Water content } \\
\text { obtained }(\%)\end{array}$ & $\begin{array}{l}\text { SD } \\
(\%)\end{array}$ & RSD (\%) & $\begin{array}{c}\text { Recovery } \\
(\%)\end{array}$ \\
\hline \multirow{4}{*}{$\begin{array}{l}\text { Before } \\
\text { subtraction of } \\
\text { blanks }\end{array}$} & $\begin{array}{l}\text { Hydranal-water } \\
\text { standard }\end{array}$ & $5.11 \pm 0.02$ & 150 & 5.10 & 0.04 & 0.8 & 99.8 \\
\hline & $\begin{array}{l}\text { Sodium tartrate } \\
\text { dihydrate }\end{array}$ & $15.66 \pm 0.05$ & 160 & 16.0 & 0.24 & 1.5 & 102.2 \\
\hline & $\begin{array}{l}\text { Apura-water oven } \\
\text { standard }\end{array}$ & $1.0 \pm 0.03$ & 170 & 1.06 & 0.03 & 1.2 & 106.3 \\
\hline & $\begin{array}{l}\text { Hydranal-water } \\
\text { standard }\end{array}$ & $5.11 \pm 0.02$ & 150 & 5.09 & 0.04 & 0.8 & 99.7 \\
\hline \multirow{2}{*}{$\begin{array}{l}\text { After } \\
\text { subtraction of } \\
\text { blanks }\end{array}$} & $\begin{array}{l}\text { Sodium tartrate } \\
\text { dihydrate }\end{array}$ & $15.66 \pm 0.05$ & 160 & 15.91 & 0.24 & 1.5 & 101.6 \\
\hline & $\begin{array}{l}\text { Apura-water oven } \\
\text { standard }\end{array}$ & $1.0 \pm 0.03$ & 170 & 0.95 & 0.01 & 1.1 & 95.0 \\
\hline
\end{tabular}

$\begin{array}{ll}\mathrm{SD} & \text { standard deviation } \\ \mathrm{RSD} & \text { relative standard deviation } \\ \mathrm{n} & \text { number of replicates }\end{array}$

Figure 2 shows typical temperature curves for the two samples. The start and stop drifts being fixed at $10 \mu \mathrm{L} / \mathrm{min}$, the occurrence of several drifts peaks showed various releases of water from the samples. Indeed water is present in diverse forms in tobacco, each corresponding to different levels of linkage energy (e.g., surface water and adsorbed water). In the temperature curve of sample A, it can be seen that all water was driven out of the sample at a temperature up to $93{ }^{\circ} \mathrm{C}$ (extraction time of $680 \mathrm{~s}$ ), in parallel the drift sank from $1004.1 \mu \mathrm{L} / \mathrm{min}$ to approximately $10 \mu \mathrm{L} / \mathrm{min}$. Above $109{ }^{\circ} \mathrm{C}$, the occurrence of several minor drift peaks indicated the degradation of the sample. In the case of sample B, different releases of water were observed between $90{ }^{\circ} \mathrm{C}$ and $100{ }^{\circ} \mathrm{C}$. A complete extraction of water observed at $99.7{ }^{\circ} \mathrm{C}$ (extraction time $890 \mathrm{~s}$ ) was clearly recognized by the occurrence of a strong drift peak at $7605.4 \mu \mathrm{L} / \mathrm{min}$. After releasing all its water this sample started to decompose above $135^{\circ} \mathrm{C}$.

Taking these observations into consideration, further attempts were made to determine the optimum extraction temperatures. All five tobacco samples (A through E) were tested in duplicate by HS-V-KFT at different oven temperatures $\left(90^{\circ} \mathrm{C}, 100^{\circ} \mathrm{C}, 110^{\circ} \mathrm{C}, 130^{\circ} \mathrm{C}\right.$, and $150^{\circ} \mathrm{C}$ ) in the isothermal mode using two sample sizes (200 and $400 \pm 10 \mathrm{mg}$ ).

The data summarized in Table 2 illustrate that the extraction time seems to be influenced by the sample size. From Table 2, it can be observed that increasing the sample size from 200 to $400 \mathrm{mg}$ generally resulted in significantly longer extraction times $(>30-60 \mathrm{~min})$. The data indicate that the extraction of water from the samples can thus be achieved within a reasonable time $(<25 \mathrm{~min})$ using a sample size of $200 \mathrm{mg}$. Figure 3 presents the yield of water extraction as a function of the temperature (isothermal mode) for the two sample sizes. It can be seen that increasing the oven temperature to $110^{\circ} \mathrm{C}$ and above gave rise to additional water formation resulting from thermal decomposition reactions, possibly of reducing sugars as previously mentioned (16), regardless of the sample type and sample size. This trend is more pronounced at $130{ }^{\circ} \mathrm{C}$ and $150{ }^{\circ} \mathrm{C}$ since the water level was found to have increased up to $4 \%$ (absolute). An increased water level resulting from thermal decomposition has been previously observed for other matrices $(20,25)$, e.g., toasted bread that was shown to be thermally unstable when exposed to a temperature above $140{ }^{\circ} \mathrm{C}(20)$. These observations demonstrate that none of the tobacco samples can be exposed to a temperature of $110{ }^{\circ} \mathrm{C}$ or above. To support these findings and select the best extraction temperature, the level of water in the samples was also determined in duplicate with the reference method V-KFT (Table 2).

A graphical representation of the water content determined by isothermal HS-V-KFT (sample amount $200 \mathrm{mg}$ ) and by $\mathrm{V}$-KFT is given in Figure 4. The comparison of the data obtained by HS-V-KFT with the results of the V-KFT measurements showed that the best agreement between the two methods for samples $\mathrm{C}$ and $\mathrm{D}$ was obtained at $90{ }^{\circ} \mathrm{C}$. For sample A, the results obtained at both $90{ }^{\circ} \mathrm{C}$ and $100{ }^{\circ} \mathrm{C}$ were slightly higher than those of the V-KFT method. The level of water extracted at $90{ }^{\circ} \mathrm{C}$ and $100{ }^{\circ} \mathrm{C}$ from sample $\mathrm{B}$ was consistent with the results obtained by $\mathrm{V}$-KFT. In the case of sample E, while $90{ }^{\circ} \mathrm{C}$ was shown to be insufficient to extract all the water contained in the sample; the extraction at $100{ }^{\circ} \mathrm{C}$ gave a concentration of water comparable to that obtained with the reference method (Figure 4). Consequently, an optimum extraction temperature of $90^{\circ} \mathrm{C}$ was selected for cast the leaf sheets (samples C and D) and $100{ }^{\circ} \mathrm{C}$ for the cut filler and extruded tobaccos (samples A, B and E).

The difference in the optimum extraction temperature between the tobacco samples could be attributed to the differences in their structure. Although the molecular matrix of cast leaf sheets and extruded shreds of tobacco presents similarities, their manufacturing process differs completely. The preparation of cast leaf sheets are based on casting a slurry of tobacco powder of $40 \mu \mathrm{m}$ in size and drying it on a belt which leads to specific physical structure with outer layer thickness of between 160 and $180 \mu \mathrm{m}$ and density of between 1.0 and $1.1 \mathrm{~kg} / \mathrm{m}^{3}$. The manufacturing of extruded shreds is based on an extrusion process of tobacco powder of $500 \mu \mathrm{m}$ in size providing a material with physical properties specific to extrusion. Extruded tobacco shreds are higher in density (1.3 to $\left.1.4 \mathrm{~kg} / \mathrm{m}^{3}\right)$ and in outer layer thickness (450 to $\left.500 \mu \mathrm{m}\right)$ 


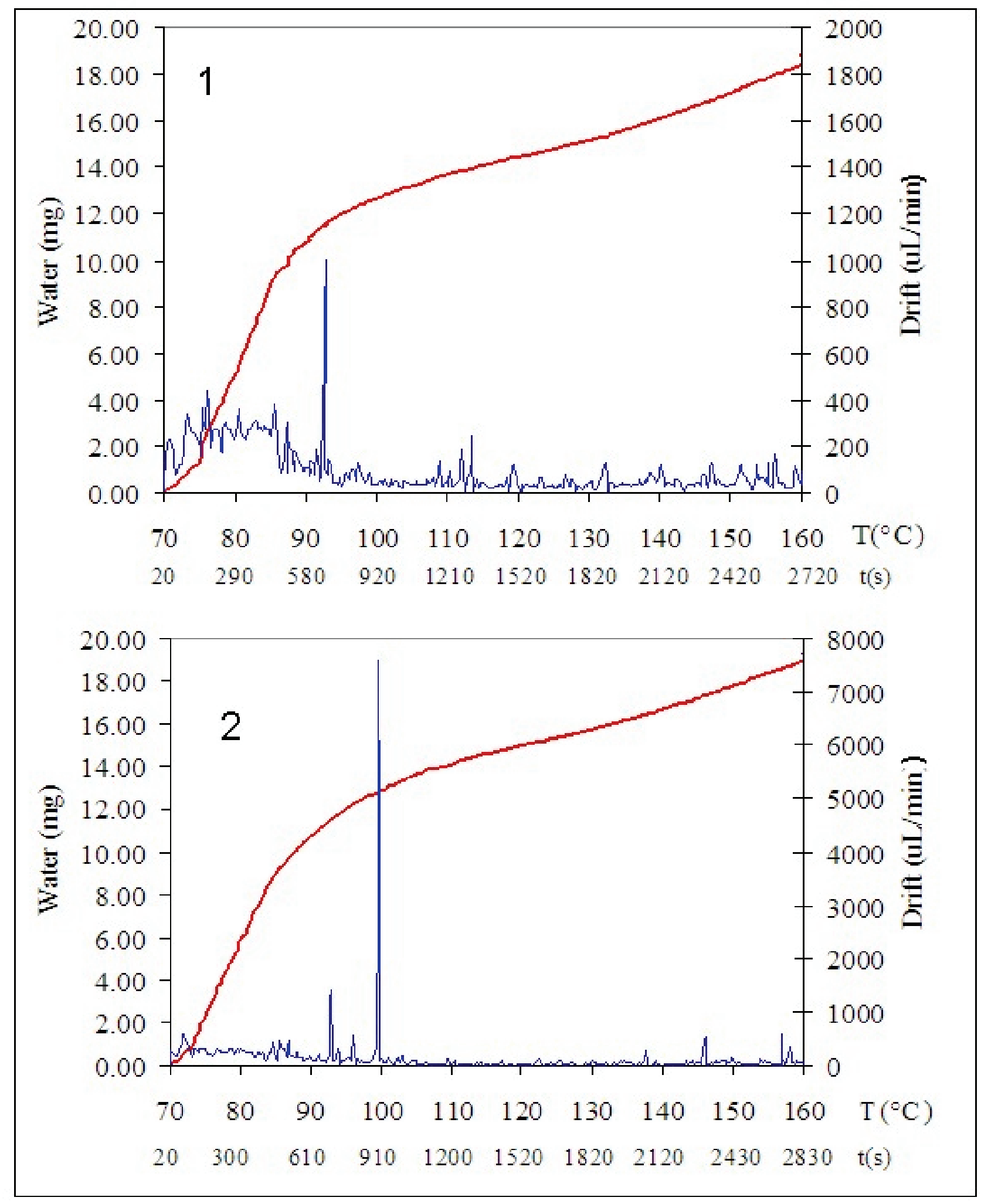

Figure 2. Temperature curves.

1

curved line peaked line
Sample A

Sample B

amount of water

drift as a as a function of temperature and extraction time 
Table 2. Results of water determination in five tobacco samples by isothermal HS-V-KFT and standard V-KFT $(n=2)$ after subtraction of three blanks.

\begin{tabular}{|c|c|c|c|c|c|c|}
\hline \multirow{3}{*}{ Sample } & \multirow{3}{*}{$\begin{array}{c}\text { V-KFT } \\
\begin{array}{l}\text { Mean water } \\
\text { content (\%) }\end{array}\end{array}$} & \multicolumn{5}{|c|}{ HS-V-KFT } \\
\hline & & \multirow[b]{2}{*}{ Temperature $\left({ }^{\circ} \mathrm{C}\right)$} & \multicolumn{2}{|c|}{ Sample size: $200 \pm 10 \mathrm{mg}$} & \multicolumn{2}{|c|}{ Sample size: $400 \pm 10 \mathrm{mg}$} \\
\hline & & & $\begin{array}{l}\text { Mean water } \\
\text { content }(\%)\end{array}$ & $\begin{array}{l}\text { Extraction time } \\
\text { (s) }\end{array}$ & $\begin{array}{l}\text { Mean water } \\
\text { content }(\%)\end{array}$ & $\begin{array}{l}\text { Extraction time } \\
\text { (s) }\end{array}$ \\
\hline \multirow{5}{*}{ A } & \multirow{5}{*}{10.17} & 90 & 10.69 & 1325.1 & 10.53 & 2017.3 \\
\hline & & 100 & 10.61 & 1004.4 & 10.73 & 1929.8 \\
\hline & & 110 & 11.35 & 1131.1 & 11.02 & 2280.8 \\
\hline & & 130 & 12.15 & 1176.2 & 12.34 & 2488.3 \\
\hline & & 150 & 13.80 & 1308.4 & 13.90 & 2615.7 \\
\hline \multirow{5}{*}{ B } & \multirow{5}{*}{10.94} & 90 & 10.95 & 1016.5 & 10.92 & 1791.5 \\
\hline & & 100 & 10.97 & 1247.6 & 11.26 & 2046.3 \\
\hline & & 110 & 11.78 & 1221.1 & 12.01 & 3483.4 \\
\hline & & 130 & 12.62 & 1462.5 & 14.05 & 3065.7 \\
\hline & & 150 & 14.13 & 1416.5 & 14.58 & 2458.8 \\
\hline \multirow{5}{*}{$\mathrm{C}$} & \multirow{5}{*}{9.75} & 90 & 9.74 & 762.3 & 9.93 & 1497.7 \\
\hline & & 100 & 9.99 & 781.7 & 10.33 & 1668.5 \\
\hline & & 110 & 10.47 & 826.2 & 10.74 & 1596.6 \\
\hline & & 130 & 11.95 & 999.2 & 12.68 & 1997.8 \\
\hline & & 150 & 13.81 & 1056.3 & 14.77 & 1925.8 \\
\hline \multirow{5}{*}{ D } & \multirow{5}{*}{9.30} & 90 & 9.29 & 705.2 & 9.38 & 1454.0 \\
\hline & & 100 & 9.57 & 775.9 & 9.82 & 1616.6 \\
\hline & & 110 & 10.09 & 824.9 & 10.41 & 1809.9 \\
\hline & & 130 & 11.19 & 1019.4 & 11.84 & 1817.2 \\
\hline & & 150 & 12.89 & 1094.1 & 13.22 & 1737.4 \\
\hline \multirow{5}{*}{$E$} & \multirow{5}{*}{8.98} & 90 & 8.41 & 803.8 & 8.90 & 1561.5 \\
\hline & & 100 & 8.87 & 764.1 & 9.24 & 1504.9 \\
\hline & & 110 & 9.35 & 831.5 & 9.65 & 1607.1 \\
\hline & & 130 & 10.30 & 862.5 & 11.17 & 1917.3 \\
\hline & & 150 & 11.74 & 993.8 & 12.23 & 1696.2 \\
\hline
\end{tabular}

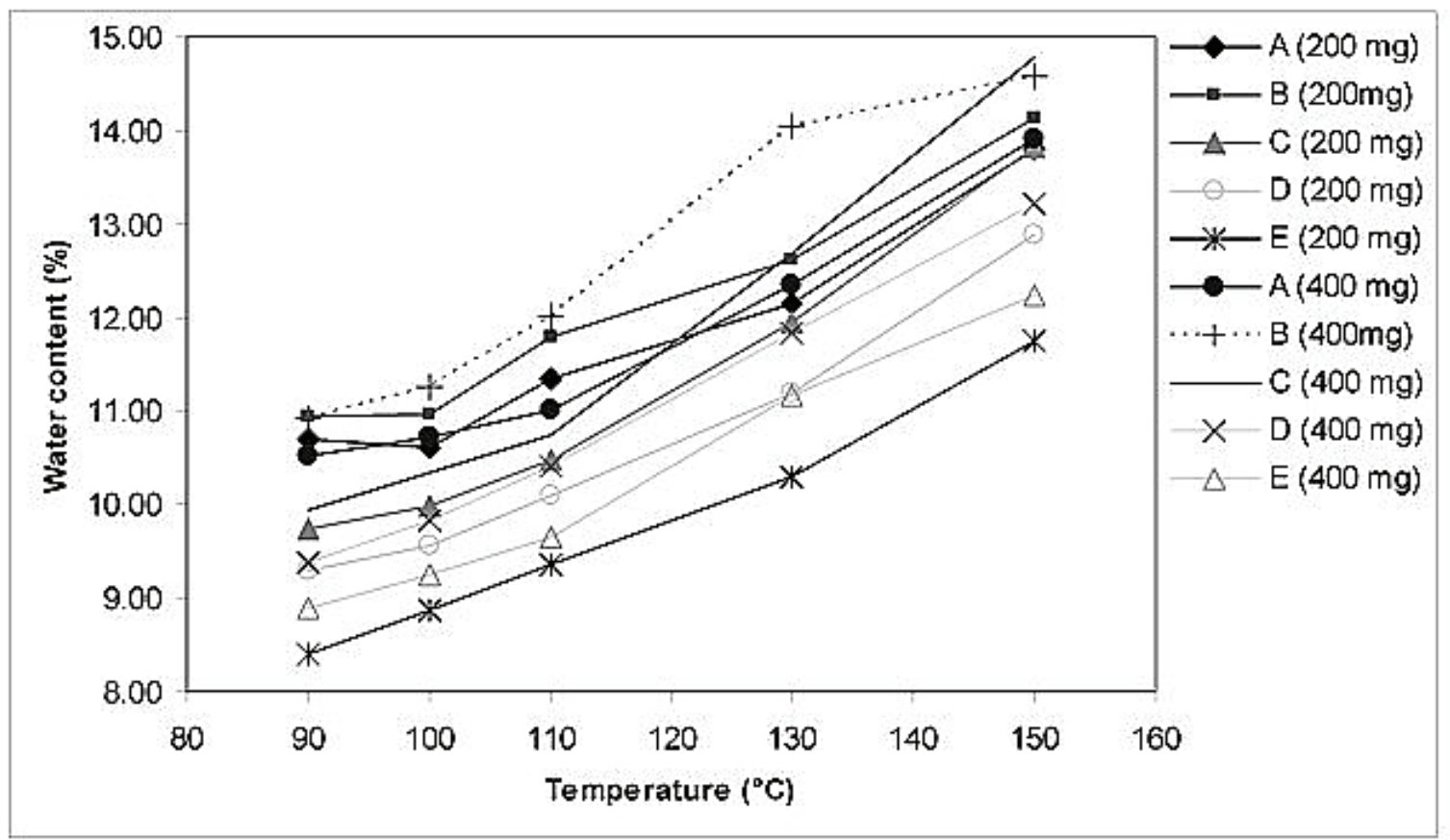

Figure 3. Water content as a function of oven temperature (isothermal mode). 
than cast leaf sheets. Because of this distinct structure a higher thermal energy is therefore required to extract the water content of extruded tobacco than of cast leaf sheets. In contrast to the latter, in cut fillers, the cellular structure remaining intact could explain a temperature of $100{ }^{\circ} \mathrm{C}$ to release its water content.

\section{Method precision}

The within-day (repeatability, r) and between-day (inter- mediate reproducibility, iR) variability (26) of the combined system were assessed by quantifying the water content in samples A and B over three different days. Five measurements were performed at $100{ }^{\circ} \mathrm{C}$ each day for each sample (sample amount $200 \pm 10 \mathrm{mg}$ ). The results are reported in Table 3 . The repeatability standard deviation values were $0.17\left(\mathrm{RSD}_{\mathrm{r}} 1.6 \%\right)$ for sample $\mathrm{A}$ and 0.1 $\left(\mathrm{RSD}_{\mathrm{r}} 0.9 \%\right)$ for sample $\mathrm{B}$. The intermediate precision standard deviations were $0.32\left(\mathrm{RSD}_{\mathrm{iR}} 3 \%\right)$ for sample A and $0.14\left(\mathrm{RSD}_{\mathrm{iR}} 1.1 \%\right)$ for sample $\mathrm{B}$.

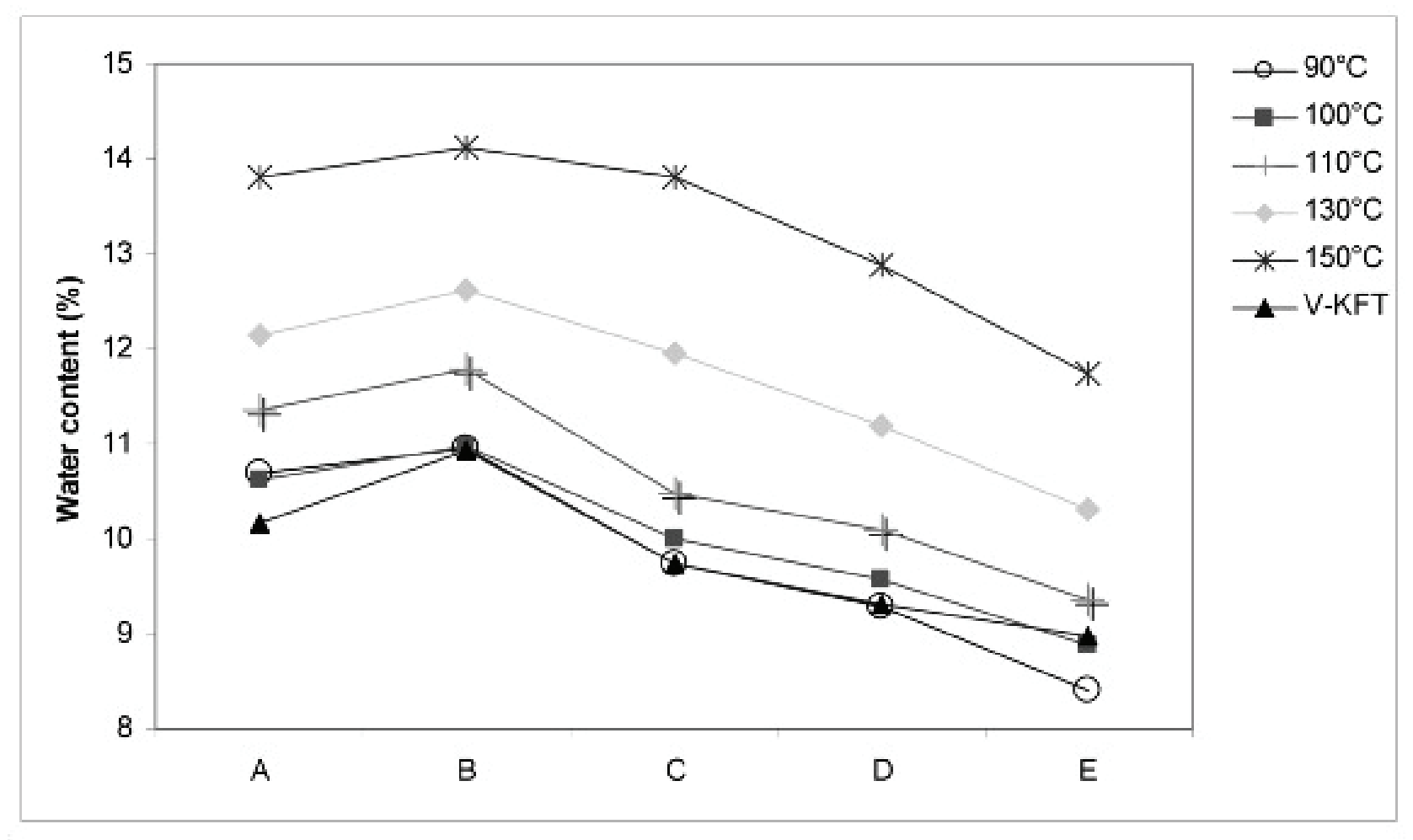

Figure 4. Determination of water content by isothermal HS-V-KFT and V-KFT for sample A to E (sample amount $200 \mathrm{mg}$ ).

Table 3. Data obtained for method precision.

\begin{tabular}{|c|c|c|c|c|c|c|c|c|c|c|c|}
\hline Sample & Day & $\mathrm{n}$ & $\begin{array}{c}\text { Mean water content } \\
(\%)\end{array}$ & SD (\%) & $\begin{array}{l}\text { Overall mean water } \\
\text { content }(\%)\end{array}$ & $\mathrm{s}_{\mathrm{r}}(\%)$ & $r$ & $\begin{array}{l}\mathrm{RSD}_{\mathrm{r}} \\
(\%)\end{array}$ & $\mathrm{s}_{\mathrm{iR}}(\%)$ & $\mathrm{iR}$ & $\begin{array}{c}\mathrm{RSD}_{\mathrm{iR}} \\
(\%)\end{array}$ \\
\hline \multirow{4}{*}{ A } & 1 & 5 & 10.73 & 0.15 & \multirow{3}{*}{10.41} & \multirow{3}{*}{0.17} & \multirow{3}{*}{0.56} & \multirow{3}{*}{1.6} & \multirow{3}{*}{0.32} & \multirow{3}{*}{1.94} & \multirow{3}{*}{3.0} \\
\hline & 2 & 5 & 10.25 & 0.24 & & & & & & & \\
\hline & 3 & 5 & 10.26 & 0.14 & & & & & & & \\
\hline & 1 & 5 & 11.12 & 0.08 & \multirow{3}{*}{11.21} & \multirow{3}{*}{0.1} & \multirow{3}{*}{0.33} & \multirow{3}{*}{0.9} & \multirow{3}{*}{0.14} & \multirow{3}{*}{0.75} & \multirow{3}{*}{1.1} \\
\hline \multirow{2}{*}{ B } & 2 & 5 & 11.24 & 0.14 & & & & & & & \\
\hline & 3 & 5 & 11.27 & 0.09 & & & & & & & \\
\hline
\end{tabular}

n number of replicates

SD standard deviation

$\mathrm{s}_{\mathrm{r}} \quad$ repeatability standard deviation

$r \quad$ repeatability

$\mathrm{RSD}_{\mathrm{r}}$ repeatability relative standard deviation

iR $\quad$ intermediate reproducibility

$\mathrm{RSD}_{\mathrm{iR}}$ intermediate reproducibility relative standard deviation 


\section{CONCLUSIONS}

A simple and fast method based on a headspace technique in combination with potentiometric Karl Fischer titration was established and validated for the quantification of the moisture level in different finished tobacco materials in the course of quality assurance. The results obtained with the headspace technique at the optimized parameters were in good agreement with those obtained by standard volumetric Karl Fischer method. The evaluation of the method precision over three days of analysis showed very good repeatability and intermediate reproducibility, illustrated by the low relative standard deviations values. HS-V-KFT can therefore be suggested as the method of choice to determine water amount in tobacco materials due to a relatively important time saving and solvent consumption reduction compared to traditional V-KFT.

\section{ACKNOWLEDGEMENTS}

We wish to thank Lynda Conroy and Joerg Diekmann for their critical review of the manuscript.

\section{REFERENCES}

1. Leffingwell, J.C.: Leaf Chemistry; in: Tobacco: Production, Chemistry and Technology; edited by D.L. Davis and M.T. Nielsen, Blackwell Science, World Agriculture Series, Oxford, 1999, pp. 265-284.

2. Banyasz, J.L.: The Thermodynamics of Tobacco-Water Interactions; Beitr. Tabakforsch. Int. 18 (1999) 189-204.

3. Walton, L.R., M.E. Casada, W.H. Henson, J.H Casada, and L.D. Swetnam: Drying Rates of Intact Burley Tobacco Plant Components; Transactions of the ASAE (1984) 219-221.

4. Babbitt, J.D.: Observation on the adsorption of water vapour by wheat; Can. J. Res. 27 (1949) 55-72.

5. Miyauchi, M., A. Miyake, and Y. Nakanishi: Characteristics of water adsorption isotherms for materials contained in a box of a tobacco product; Dry. Technol. 13 (1995) 351-370.

6. Menkov, N.D. and K.T. Dinkov: Moisture Sorption Isotherms of Tobacco Seeds at Three Temperatures; J. Agr. Eng. Res. 74 (1999) 261-266.

7. Nakanishi, Y.: Physical Properties of Leaf Tobacco; in: Tobacco Production, Chemistry and Technology, edited by D.L. Davis and M.T. Nielsen, Blackwell Science, World Agriculture Series, Oxford, 1999, pp. 313-319.

8. International Organisation for Standardization (ISO): ISO 6488:1981 Tobacco - Determination of water content (Reference method); ISO, Geneva, Switzerland, 1981.

9. Brunnemann, K.D., J. Qi., and D. Hoffmann: Chemical profile of two types of oral snuff tobacco; Food Chem. Toxicol. 40 (2002) 1699-1703.

10. Arany, S. and G. Erdei: Applicability of standardized methods for the determination of moisture content, with particular respect to tobacco treated with moistur- izing agents and tobacco foils; Elelmiszervizsgalati 29 (1983) 47-57.

11. Djordjevic, M.V., D. Hoffmann, T. Glynn, and G.N. Connolly: US commercial brands of moist snuff, 1994. I. Assessment of nicotine, moisture, and $\mathrm{pH}$; Tob. Control 4 (1995) 62-66.

12. Waltz, P. and M. Haeusermann: Determination of the Tobacco Humidity Comparison of the Azeotropic Benzene Distillation with Oven Drying (Zur Bestimmung der Feuchtigkeit im Tabak: Vergleich zwischen der Azeotropen Destillation mit Benzol und der Trocknung im Ofen); Beitr. Tabakforsch. 1 (1962) 343-346.

13. von Bethmann M., G. Lipp, and H. van Nooy: Estimation of Moisture Content of Tobacco (Feuchtigkeitsbestimmung im Tabak); Beitr. Tabakforsch. 1 (1961) 19-29.

14. Results of a Collaborative Examination on the Water Content of Tobacco (Ergebnisse der Ringuntersuchung zur Feuchtigkeitsbestimmung); Beitr. Tabakforsch. 1 (1962) 337-341.

15. Casada, M.E. and L.R. Walton: Tobacco Moisture Content Determination by Microwave Heating; Transactions of the ASAE (1985) 307-309.

16. Fryd, C.F.M. and P.R. Kiff: The determination of moisture in tobacco; Analyst 76 (1951) 25-32.

17. CORESTA Recommended Method 56: Determination of water in tobacco and tobacco products by Karl Fischer method; 2002.

18. International Organisation for Standardization (ISO): ISO 6488:2004 Tobacco and tobacco products - Determination of water content - Karl Fischer method; ISO, Geneva, Switzerland, 2004.

19. CORESTA Recommended Method 57: Determination of Water in Tobacco and Tobacco Products by Gas Chromatographic Analysis; (2002).

20. Kestens, V., P. Conneely, and A. Bernreuther: Vaporisation coulometric Karl Fischer titration. A perfect tool for water content determination of difficult matrix reference materials; Food Chem. 106 (2008) 1454-1459.

21. Barron, L.J.R., Y. Redondo, M. Ortigosa, M. Carbonell, S. Garcia, P. Torre, M. De Renobales, and E. Fernandez-Garcia: Comparison of dynamic headspace methods used for the analysis of the volatile composition of Spanish PDO ewe's raw milk cheeses; Lait 85 (2005) 491-513.

22. Mehinagic, E., C. Prost, and M. Demaimay: Optimization of extraction of apple aroma by dynamic headspace and influence of saliva on extraction of volatiles; J. Agric. Food Chem. 52 (2004) 5175-5182.

23. Hinz, D.C.: Evaluation of methods for the determination of water in substances with unknown chemical and thermal behavior; J. Pharmaceut. Biomed. 43 (2007) 779-783.

24. Supartono, W. and H.D. Isengard: Combination of Karl Fischer titration with drying oven as an alternative method to determine the water content in coriander; Adv. Food Sci. 19 (1997) 47-50.

25. Schöffski, K.: New Karl Fischer reagents for the water determination in food; Food Control 12 (2001) 427-429. 
26. International Organisation for Standardization (ISO): ISO 5725-1:1994 Accuracy (trueness and precision) of measurement methods and results - Part 1: General principles and definitions; ISO, Gneneva, Switzerland, 1994.

Corresponding author:

Michel Rotach

Philip Morris International R\&D

Philip Morris Products S.A.

5 Quai Jeanrenaud

2000 Neuchâtel, Switzerland

E-mail:Michel.Rotach@pmi.com 